\title{
Phytotoxicity of the extracts of Lonchocarpus muehlbergianus Hassl. (Fabaceae) leaflets and galls on seed germination and early development of lettuce
}

\author{
Denis Coelho de Oliveira ${ }^{1}$, Geraldo Luiz Gonçalves Soares ${ }^{2}$ and Rosy Mary dos Santos Isaias ${ }^{1,3}$
}

Received: November 26, 2007. Accepted: April 3, 2008

\begin{abstract}
RESUMO - (Fitotoxidade diferencial dos extratos aquosos de folíolos e galhas de Lonchocarpus muelhbergianus Hassl. (Fabaceae) na germinação e desenvolvimento inicial de alface). Galhas induzidas por Euphalerus ostreoides (Hemiptera: Psyllidae) produzem alterações estruturais e químicas nos folíolos de Lonchocarpus muehlbergianus. As galhas, em geral, atuam como drenos de fotoassimilados podendo acumular tanto compostos do metabolismo primário, associados à alimentação do inseto quanto do metabolismo secundário, relacionados às inter-relações da planta-hospedeira com o galhador e demais níveis tróficos associados. Tecidos sadios e galhados de L. muehlbergianus são ricos em metabólitos com efeito alelopático potencial. Este trabalho compara efeitos alelopáticos dos extratos aquosos de folíolos sadios e galhas de L. muehlbergianus nas sementes e plântulas de Lactuta sativa, avalia o impacto químico produzido pelo inseto galhador e níveis tróficos associados. Os resultados obtidos podem lançar novas perspectivas sobre o impacto químico produzido pelo inseto indutor nos demais níveis tróficos associados à planta hospedeira. Os extratos foram obtidos através de maceração estática em água destilada (5\% p/v). Os tratamentos consistiram de extratos aquosos e seus filtrados em polivinilpirrolidona (PVP). Depois de sete dias, as plântulas foram medidas e as raízes fixadas em FAA $_{50}$ para análises anatômicas. Extratos aquosos de folíolos sadios e galhas, e seus filtrados em PVP, inibiram significativamente a germinação de sementes, não apresentando diferenças entre os dois grupos. Tratamentos com extratos aquosos reduziram a velocidade de germinação das sementes e o comprimento do eixo vegetativo. As alterações nos tecidos vegetais confirmam os sintomas de fitotoxidade de substâncias aleloquímicas evidenciados pela não diferenciação dos pêlos absorventes, colapso das demais células epidérmicas e desorganização do córtex. A diferença entre os tratamentos indica que a formação da galha altera o metabolismo do folíolo sadio e isso poderia influenciar outros níveis tróficos associados ao sistema galhador-planta hospedeira.
\end{abstract}

Palavras-chave: alelopatia, Euphalerus ostreoides, galhas, herbivoria, Lonchocarpus muehlbergianus

\begin{abstract}
Phytotoxicity of the extracts of Lonchocarpus muehlbergianus Hassl. (Fabaceae) leaflets and galls on seed germination and early development of lettuce). Galls induced by Euphalerus ostreoides (Hemiptera: Psyllidae) cause structural and chemical alterations on Lonchocarpus muehlbergianus leaflets. Healthy and galled leaflet tissues of this plant species are rich in secondary metabolites with potential allelopathic effects. This research compares the allelopathic effects of the aqueous extracts of $L$. muehlbergianus leaflets and galls on seeds and seedlings of Lactuta sativa, and evaluates the chemical impact produced by a gall-inducing insect on the other trophic levels associated with it. The extracts were obtained through static maceration in distilled water (5\% p/v). The treatments consisted of aqueous crude extracts and those previously filtered in polyvinylpirrolidone (PVP). After seven days, seedling height was measured, and the radicles were fixed in $\mathrm{FAA}_{50}$ for anatomical analyses. Healthy leaflet and gall aqueous extracts, and those filtered in PVP, significantly inhibited seed germination, with no significant differences between the two groups. Treatments with aqueous extracts reduced seed germination speed and vegetative axis length. Plant tissue alterations confirm the phytotoxicity of allelochemical substances present in the extracts. The differences among the treatments indicated that gall formation altered L. muehlbergianus leaflet metabolism, and this could influence the other trophic levels associated with this gall inducing-host plant system.
\end{abstract}

Key words: allelopathy, Euphalerus ostreoides, gall, herbivory, Lonchocarpus muehlbergianus

\section{Introduction}

Allelopathy is any direct or indirect, harmful or beneficial effect that a plant or microorganism exerts on another plant by the release of chemical compounds into the environment (Rice 1984). This plant-plant interaction involves either abiotic or biotic stresses potentialized by multiple substances that may act synergically (Einhelling 1996).

Plants, unlike animals, do not move to escape from environmental challenges. Therefore, these living organisms developed sophisticated structural responses

\footnotetext{
1 Universidade Federal de Minas Gerais, Instituto de Ciências Biológicas, Departamento de Botânica, Av. Antonio Carlos 6627, Pampulha, 31270-901 Belo Horizonte, MG, Brasil

2 Universidade Federal do Rio Grande do Sul, Instituto de Biociências, Departamento de Botânica, Av. Bento Gonçalves 9500, Campus do Vale, 91501-970 Porto Alegre, RS, Brasil

3 Corresponding Author: rosy@icb.ufmg.br
} 
to a sort of chemical, physical or biological stimuli, to which plants react with atypical growth, stressmetabolite synthesis or cellular autolysis (Kraus 1997; Dangl \& Jones 2000).

Complex forms of atypical development can produce galls, structures originated through cellular hypertrophy, tissue hyperplasia, and inhibition or modification of cell development in response to the attack of inducing organisms such as virus, bacteria, fungi, nematodes, acari or insects (Mani 1964). Besides the structural alterations in host plant tissues, gall inducing herbivores produce biochemical modifications, noticed either on primary or secondary specific metabolites (Hartley 1998). These metabolites, nutritive compounds and growth hormones are reallocated from the healthy tissues to the gall site (Leicht 1994; Nymam 2000) which functions as a sink. Oliveira et al. (2006) demonstrated that the healthy tissues and the galls induced by Euphalerus ostreoides on Lonchocarpus murhlbergianus leaflets accumulate nutritive substances, such as starch and lipids, as well as phenolic and flavonoidic derivatives (flavones, flavonols, and flavanones). Also, in these gall tissues, the flavonic compounds formed oxonium salts by the reaction with sulphuric acid, which did not occur in healthy tissues. Therefore, the synthesis of oxonium salt precursors may be a specific response to the biotic stress induced by the endophytophagous insect.

Secondary metabolites with allelochemical potential have great chemical diversity and are involved in many metabolic and ecological processes (Rice 1984; Einhelling 1985; Cruz-Ortega et al. 1988; 1990). These substances can belong to different categories of secondary metabolites, such as phenols, terpenes, and alkaloids, which may be detected in different organs, including leaves, flowers, fruits, and buds of many plant species (Miró et al. 1998; Delachiave et al. 1999; Aires et al. 2005; Maraschin-Silva \& Aqüila 2006). The galls, considered by Meyer \& Maresquelle (1983) as plant organs, can accumulate metabolites with distinct allelopathic potential when compared to other plant parts.

The host plant species, Lonchocarpus muehlbergianus Hassl. (Fabaceae), presents galls induced by Euphalerus ostreoides Crawf. (Psyllideae) on its second order veins. Besides structural alterations, gall induction and development produce chemical alterations noticed mainly in relation to flavonoidic derivatives, as attested by Oliveira et al. (2006).

Flavonoids are largely known by their action in plant defensive mechanisms against herbivores and pathogens; these compound concentrations are altered or allocated as a function of environmental stress as well (Tang et al. 1995; Stephanou \& Manetas 1997). The present investigation compares the effects of the aqueous extracts of leaflets and galls induced by Euphalerus ostreoides in Lonchocarpus muehlbergianus on seed germination and early development of an indicative species, Lactuta sativa. The results obtained may also set up new perspectives on the chemical impact produced by the gall-inducing insect on the other trophic levels associated with this host plant.

\section{Material and methods}

For evaluation of the allelopathic potential of the aqueous extracts of healthy leaflets and galls induced by Euphalerus ostreoides on Lonchocarpus muehlbergianus, plant material was collected from 10 specimens located at the Campus Pampulha of Universidade Federal de Minas Gerais, in Belo Horizonte, Minas Gerais. An exsiccate of the material was deposited in the Herbarium BHCB under registration number 23110.

Extract obtention - Aqueous extracts from healthy leaflets, mature galls and healthy portion of galled leaflets were made. These extracts were used for the seed germination and early development bioassays. For obtaining the extracts, material was triturated with the aid of a blender for five minutes and then weighed. Each material was submitted to static maceration for 24 hours, centrifuged, filtered in paper-filter and the supernatant was collected. All of the extracts were prepared with the proportion of $5 \mathrm{~g}$ of triturated plant material into 100 $\mathrm{ml}$ of distilled water. This was considered the crude extract ( $100 \%$ concentration). In order to control the phenolic activity influence, the aqueous extracts were filtered in polyvinylpirrolidone (PVP) (Soares et al. 2002). The effects of the aqueous crude extracts and those filtered in PVP were compared with each other and with the control (distilled water).

Osmotic potential - The osmotic potential of the aqueous leaflet and gall extracts of L. muehlbergianus were measured using an osmometer (Precision Systems mosmette ${ }^{\mathrm{TM}}$ ). The effect of polyetileneglycol (PEG) solutions with the same osmolarity was tested on seed germination, germination speed and seedling development of lettuce using the same methodology carried out with the aqueous extracts.

Bioassays - An indicative species, Lactuta sativa cv "Grand Rapids", was used for germination and early development bioassays.

For the germination tests, healthy leaflet extract (HLE), gall extract (GE), healthy portion of galled leaflet extract (HPGLE) and each of these extracts filtered in PVP were used. The control group was treated with distilled water. Seed germination tests were accomplished in $9 \mathrm{~cm}$ Petri dishes with two paper-filter sheets 
moistened with $8 \mathrm{ml}$ of each extract. Four simultaneous replicates of 25 lettuce seeds were used. The germination tests were driven in a germination chamber at $25^{\circ} \mathrm{C}$ with a 12 hour photoperiod. The number of germinated seeds was counted daily during seven days. Seeds that presented $2 \mathrm{~mm}$ of radicle bulge were considered germinated (see Brasil 1992). Germination percentage and germination speed were calculated according to Labouriau \& Valadares (1976).

Morphological analysis - The morphological evaluations were performed at the end of the experimental period in 100 seedlings obtained from 4 Petri dishes each with 25 seeds. The height of the seedlings $(\mathrm{mm})$, considered as the distance from lap to the shoot apex, and the length of the seedlings $(\mathrm{mm})$, considered as the distance from lap to the radicle apex, were measured.

For anatomical analyses, the 7-day seedlings were fixed in $\mathrm{FAA}_{50}$ for 48 hours, dehydrated in buthanol series (Johansen 1940) and infiltrated with Paraplast ${ }^{\circledR}$ (Kraus \& Arduin 1997). Anatomical sections were obtained in rotative microtome $(12-16 \mu \mathrm{m})$, stained with astra blue and safranin (Bukatsch 1972), modified to 0.5\% concentration, washed in distilled water and mounted with jelly glycerin (Jensen 1962).

Statistical analysis - The results were submitted to ANOVA, followed by the Tukey test at $5 \%$ probability. Data that did not fit the normal distribution were submitted to Kruskal-Wallis test at 5\% probability using the software JUMP (SAS 2002).

\section{Results}

Germination bioassays - Either the healthy leaflet extract (HLE) or the gall extract (GE) significantly inhibited germination of $L$. sativa. However, the healthy portions of galled leaflet extract (HPGLE) did not significantly affect germination percentage (Fig. 1). The action of HLE, GE, and HPGLE and those filtrated in polyvinylpirrolidone (HLE+PVP, GE+PVP and HPGLE+PVP) did not show significant differences in relation to the control group (Fig. 2).

HPGLE and HPGLE + PVP did not inhibit L. sativa germination, but caused small necrosis spots on the young radicle. HLE and GE did not affect seedling emergence, but its development was reduced, the radicle cap was totally oxidized, and the tissues were softened and degraded.

The allelochemical effects of HLE, HPGLE and GE of Lonchocarpus muehlbergianus on lettuce seeds were more evident on germination speed (Fig. 3) and seedling length (Fig. 4) than on the final germination percentage.

No significant effect on lettuce seed germination was observed with the treatments with PEG solutions (Tab. 1). Therefore, the results obtained on germination tests with HLE, HPGLE and GE of L. muehlbergianus

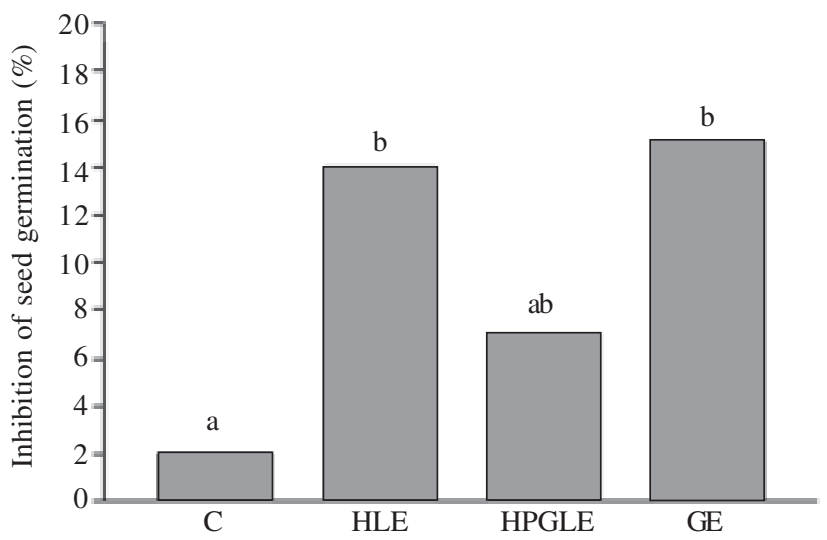

Figure 1. Inhibiton percentage of Lactuta sativa seed germination under the effect of leaflet and gall aqueous extracts of Lonchocarpus muehlbergianus Hassl. Control (C), healthy leaflets extract (HLE), healthy portion of galled leaflets extract (HPGLE) and gall extract (GE). Same letters indicate that the values do not differ significantly among themselves at $5 \%$ probability by Kruskal-Wallis test.

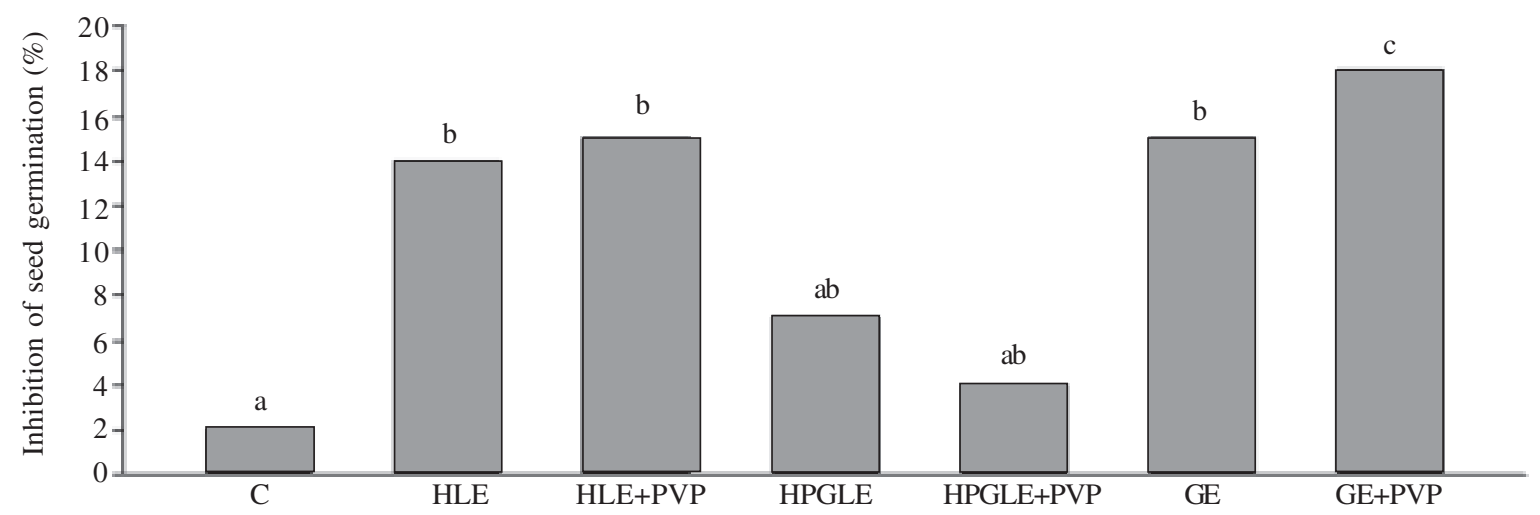

Figure 2. Inhibition percentage of Lactuta sativa seed germination under the effects of leaflet and gall aqueous extracts of Lonchocarpus muehlbergianus Hassl. and those filtrated in polyvinylpirrolidone (PVP). Control (C), healthy leaflets extract (HLE), healthy portion of galled leaflets extract (HPGLE) and gall extract (GE). Same letters indicate that the values do not differ significantly among themselves at 5\% probability by Kruskal-Wallis test. 
were due to the presence of allelopathic activity, and not to a difference in the osmotic potential of the extracts.

Morphological analysis - Shoot growth surpassed radicle growth, and the ratio shoot:radicle increased in the treatments with aqueous extracts when compared to the control. EG drastically affected radicle growth, while HPGLE was less effective when compared to HLE and EG (Fig. 4).

The phytotoxic effects of the allelochemicals caused anatomical malformations on lettuce seedlings. Alterations in tissue organization of radicles treated with HLE, GE, and HPGLE were observed. The radicle of the lettuce control group developed simple epidermis with polygonal cells, cortex with approximately seven layers of round cells, and a distinct endodermis. The vascular cylinder presented two protoxylem poles facing the outside surface of the radicle (Fig. 5). In seedlings

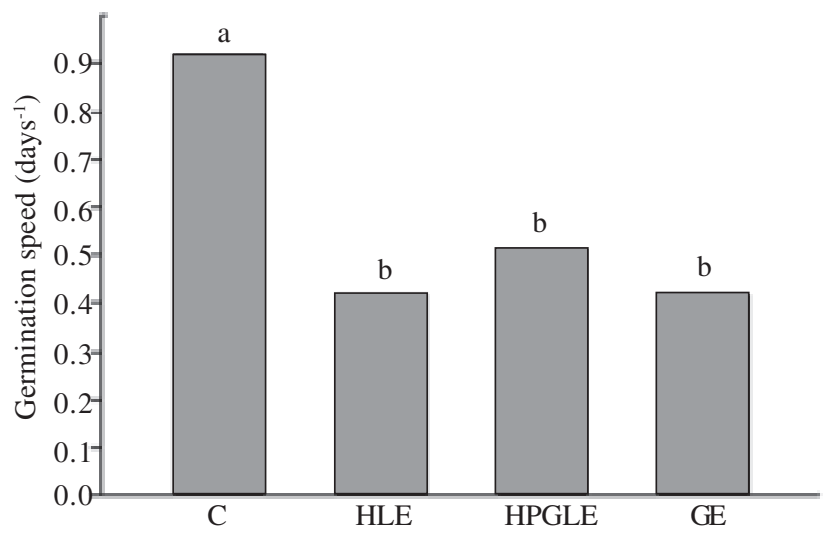

Figure 3. Germination speed of Lactuta sativa seeds under the effect of leaflet and gall aqueous extracts of Lonchocarpus muehlbergianus Hassl. Control (C), healthy leaflet extract (HLE), healthy portion of galled leaflet extract (HPGLE) and gall extract (GE). Same letters indicate that the values do not differ significantly among themselves at $5 \%$ probability by Kruskal-Wallis test.

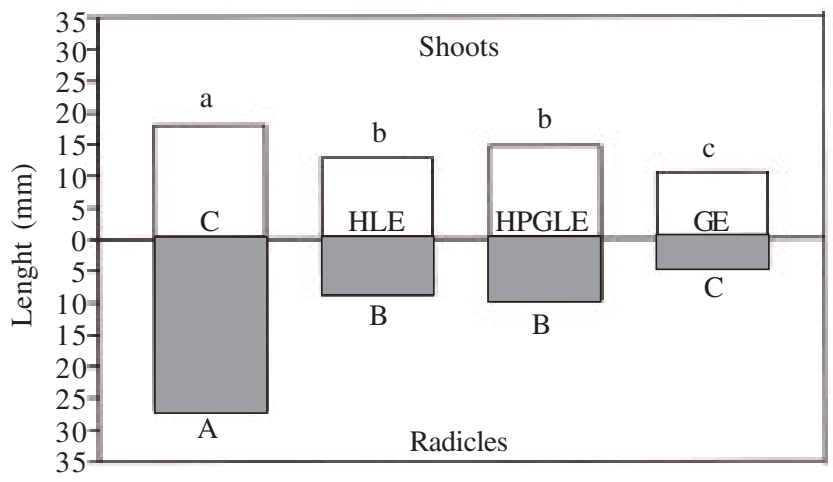

Figure 4. Average size (mm) of shoots and radicle of Lactuta sativa seedling treated for seven days with aqueous extracts Lonchocarpus muehlbergianus Hassl. Control (C), healthy leaflet extract (HLE), healthy portion of galled leaflet extract (HPGLE) and gall extract (GE). Same letters indicate that the values do not differ significantly among themselves at $5 \%$ probability by Tukey test.
Table 1. Effect of PEG solutions on seed germination (G\%), germination speed (GS), shoot length (SL) and root length (RL) of lettuce (Lactuta sativa).

\begin{tabular}{ccccc}
\hline $\begin{array}{c}\text { PEG } \\
\text { (osmotic potential, MPa)* }\end{array}$ & G\% & GS & $\begin{array}{c}\text { SL } \\
(\mathrm{mm})\end{array}$ & $\begin{array}{c}\text { RL } \\
(\mathrm{mm})\end{array}$ \\
\hline-0.14 & 98 & 0,93 & 17,2 & 25,9 \\
-0.17 & 98 & 0,93 & 16,9 & 25,8 \\
-0.16 & 98 & 0,94 & 17,0 & 25,9 \\
-0.14 & 98 & 0,92 & 17,0 & 25,7 \\
-0.10 & 98 & 0,94 & 16,8 & 26,0 \\
-0.12 & 99 & 0,94 & 16,7 & 25,7 \\
\hline
\end{tabular}

* These values correspond to the osmotic potential (Mpa) of the HLE, HLE + PVP, HPGLE, HPGLE + PVP, EG and EG + PVP. There is no significant difference between the values according to Kruskal-Wallis test (G\% and GV) and Tukey test (SL and RL).

submitted to HLE, GE, and HPGLE, the epidermal and subepidermal cells collapsed (Fig. 6), and a total absence or decrease in number of root hairs occurred. Also, cell hypertrophy, cortical hyperplasia, and no alteration of the vascular cylinder were noticed. An increase in lateral root differentiation was observed in the seedlings treated with all the extracts.

\section{Discussion}

Several phenolic compounds have been detected in the genus Lonchocarpus (Labouriau \& Valadares 1976; Fang \& Casida 1999; Alavez-Solano et al. 2000; BorgesArgaéz et al. 2000; Oliveira et al. 2006). Even though these substances are considered as potential allelochemicals (Tang et al. 1995; Jefferson \& Pennacchio 2003), in Lonchocarpus muehlbergianus HLE, GE, and HPGLE, phenolic substances seemed not to be related to the phytotoxic effects observed on the indicative species, for the effects of the phenolic control, i.e., the PVP filtrated extracts, were similar.

Most substances with allelochemical activity come from the secondary metabolism, since in plant evolution these substances represented some protection against microorganisms, by inhibiting their action or stimulating plant growth or development (Waller 1999). Besides plant structural alterations, the association with gallinducing herbivores may produce biochemical modifications affecting primary and secondary specific metabolites (Hartley 1998). In the leaflets of L. muehlbergianus, the impact caused by E. ostreoides produced chemical alterations, which were noticed in relation to the storage of substances from the secondary metabolism, especially flavonoidic derivatives (Oliveira et al. 2006). It could be suggested that some secondary substances were responsible for the distinct allelopathic action of L. muehlbergianus HLE, GE, and HPGLE on the indicative species. 


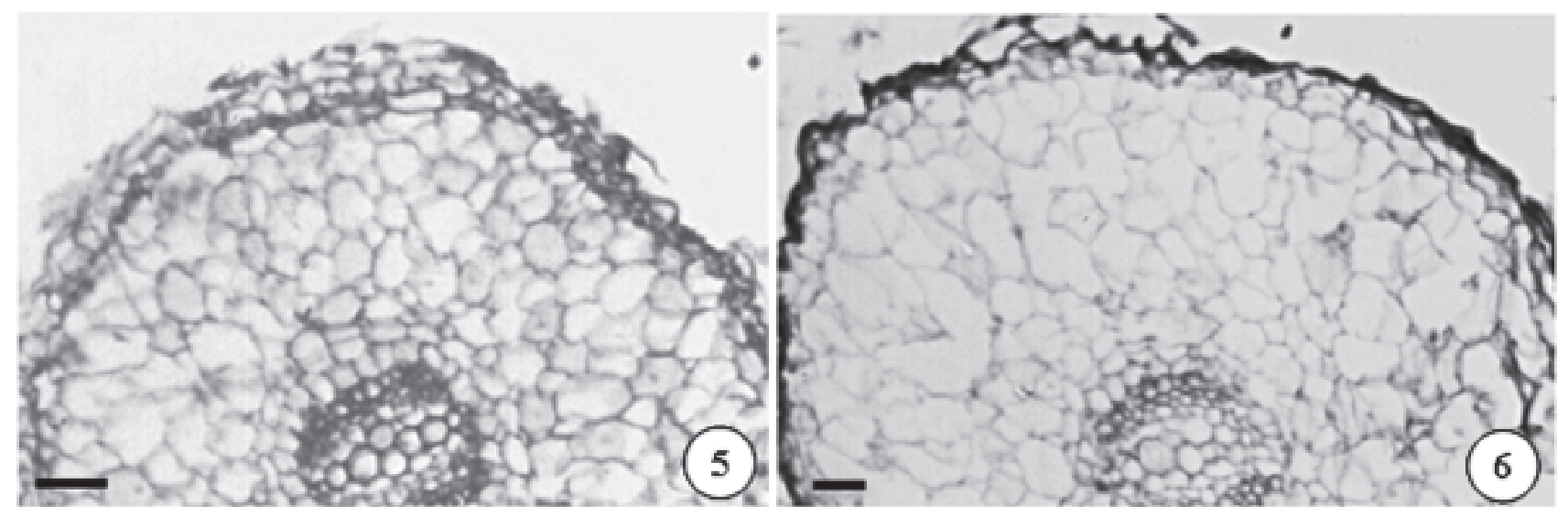

Figure 5-6. Transverse sections of Lactuta sativa radicle. 5. Radicle of the control group with simple epidermis, polygonal cells, cortex with approximately seven layers of round cells. The last layer constituted a conspicuous endodermis. 6 . Radicle treated with the aqueous extracts where the epidermal and subepidermal cells collapsed. Bars $=100 \mu \mathrm{m}$.

The allelochemical effects of L. muehlbergianus on lettuce seeds were more evident on germination speed and seedling length than on the final germination percentage, an effect similar to that observed by Periotto (2004). Still, the results from Ferreira and Áquila (2000) pointed to germination as less sensitive to allelochemicals than seedling growth, because allelopathic substances could induce abnormal seedling organ emergence, being radicle necrosis one of the most common symptoms as was observed in the lettuce radicles treated with L. muehlbergianus aquous extracts.

The most frequent parameter used to evaluate the allelopathic effects on plant growth is the total length of the seedling (Jacobi \& Ferreira 1991; Inderjit \& Dakshini 1995; Pratley et al. 1999). Indeed, L. muehlbergianus extracts, mainly GE, produced a drastic effect in shoot:radicle ratio.

Morphological and anatomical alterations in the radicle of $L$. sativa submitted to the aqueous extracts of $L$. muehlbergianus could be used as a pattern to evaluate the symptoms provoked by phytotoxic substances of species with allelopathic potential. In seedlings submitted to the treatments, the epidermal and subepidermal cells collapsed, and a total absence or decrease in number of root hairs was observed, being the latter a very sensitive parameter for allelopathy experiments according to Miró et al. (1998). Also, Dayan et al. (2000) attributed the formation of lateral roots to disturbances in seedling hormonal balance due to allelopathic substances.

Many factors can be influenced by allelopathy, such as soil microbial ecology, nutrient dynamics, as well as some other abiotic and biotic factors. Allelochemicals play key roles in structuring other trophic levels, especially affecting predators and pests (Dakshini et al. 1999). Gall formation in L. muehlbergianus is a biotic factor that influences allelochemical production and allocation.

With the obtained data, it was proved that $L$. muehlbergianus possesses potential allelopathic activity on the seeds and seedlings of $L$. sativa, and also that, substances with allelopathic potential are probably being mobilized to the galls, which function as sinks, as a response to the activity of E. ostreoides. It was also proved that this gall inducing herbivore manipulated host plant metabolism, which was reinforced by the alterations observed on plant tissue level. Our results indicated the presence of water soluble phytotoxic allelochemicals (compounds) in leaflets and galls of L. muelhbergianus. Also, the low presence of allelochemicals in the healthy portion of galled leaflets (HPGLE) when compared to healthy leaflets (HLE) and galls (GE) reinforced the gall as a strong sink of compounds either from other leaflets or its own host leaflet.

Ferreira et al. (1990) found a reduction of $62 \%$ in mortality from the first to the second week after E. osteoides gall induction on L. muehlbergianus leaflets. Furthermore, the highest phytotoxic effects of mature galls might be related to an increase of $L$. muelhbergianus defense against the other guild herbivores.

The aqueous extracts of HLE and GE of L. muhelbergianus present allelopathic potential. Furthermore, the distinct allelopathic actions of GE and HPGLE corroborate the proposal of the galls as active sinks and should indicate new perspectives for the study of chemical ecology on gall inducing-host plant relationships and the effects of allelochemicals not only in plant development but also on the interaction with other trophic levels associated with the system, besides characterizing the biotechnological potential of galls as allelochemical concentrators. 


\section{Acknowledgments}

The authors would like to thank $\mathrm{CNPq}$ and FAPEMIG (CBB 782/06) for financial support, and biologists Ana S.F.P. Moreira and Marina N. Alvim for critical reading of the manuscript.

\section{References}

Aires, S.S.; Ferreira, A.G. \& Borghetti, F. 2005. Efeito alelopático de folhas e frutos de Solanum lycocarpum A.St.-Hil. (Solanaceae) na germinação e crescimento de Sesanum indicum L. (Pedaliaceae) em solo sob três temperaturas. Acta Botanica Brasilica 19: 339-344.

Alavez-Solano, D.; Reyes-Chilpa, R.; Jiménez-Estrada, M.; GómezGaribay, F.; Chavez-Uribe, I. \& Souza-Sánchez, M. 2000. Flavanones and 3-hydroxyflavanones from Lonchocarpus oaxacensis. Phytochemistry 55: 953-957.

Borges-Argáez, R.; Pena-Rodríguez, L.M. \& Waterman, P.G. 2000. Flavonoids from the item bark of Lonchocarpus xuul. Phytochemistry 54: 611-614.

Brasil 1992. Regras para Análise de Sementes. SNDA/DNDV/ CLAV. Brasília, Ministério da Agricultura e Reforma Agrária.

Bukatsch, F. 1972. Bermerkungen zur Doppelfärbung AstrablauSafranin. Mikrokosmos 61: 255.

Cruz-Ortega R.; Anaya, A.L.; Gavilanes-Ruiz, M.; Sanches-Nieto, S. \& Jiménez Estrada, M. 1990. Effect of diacetyl piquerol on the $\mathrm{H}^{+}$-ATPase activity of microsomes from Ipomarca purpurca. Journal of Chemical Ecology 16: 2253-2261.

Cruz-Ortega R.; Anaya, A.L.; \& Ramos L. 1988. Effects of allelopathic compouds of corn pollen on respiration and cellular division of watermelon. Journal of Chemical Ecology 14: 71-86.

Dakshini, K.M.; Foy, C.L. \& Inderjit. 1999. Allelopathy: one component in a multifaceted approach to ecology. Pp. 3-14. In: Inderjiti; K.M.M. Dakshini \& C.L. Foy (eds.). Principles and Pratices in Plant Ecology: Allelochemicals Interaction. Boca Raton, FL.CRC Press.

Dangl, J.L. \& Jones, J.D.G. 2001. Plant pathogens and integrated defence responses to infection. Nature 411: 826-833.

Dayan, F.E.; Romagni, J.G. \& Duke, S.O. 2000. Investigating the mode of action of natural phytotoxins. Journal of Chemical Ecology 26: 2079-2094.

Delachiave, M.E.A.; Rodrigues, J.D. \& Ono, E.O. 1999. Efeitos alelopáticos de losna (Artemisia absinthium L.) na germinação de sementes de pepino, milho, feijão e tomate. Revista Brasileira de Sementes 21: 265-269.

Einhellig, F.A. 1985. Allelopathy - a natural protection, allelochemicals. Pp. 161-200. In: N.B. Mandava (ed.). Handbook of natural pesticides: methods v.1 theory, pratice, and detection. Boca Raton, FL, Ed. CRC Press.

Einhelling, F.A. 1996. Interaction involving allelopathy in crop systems. Agronomy Journal 88: 886-893.

Fang, N. \& Casida, J.E. 1999. New bioactive flavonoids and stilbenes in cube resin insecticide. Journal of Natural Products 62: 205-210.

Ferreira, A.G. \& Aquila, M.E.A. 2000. Alelopatia: uma área emergente da ecofisiologia. Revista Brasileira de Fisiologia Vegetal 12(Especial): 175-204.

Ferreira, S.A.; Fernandes, G.W. \& Carvalho, L.G. 1990. Biologia e história natural de Euphalerus ostreoides (Hemiptera: Psyllidae) cecidógeno de Lonchocarpus guilleminianus (Leguminosae). Revista Brasileira de Biologia 50: 417-423.

Hartley, S.E. 1998. The chemical composition of plant galls: are levels of nutrients and secondary compounds controlled by the gall former? Oecologia 113: 492-501.

Inderjit \& Dakshini, K.M.M. 1995. On laboratory biossays in allelopathy. Botanical Review 61: 28-44.
Jacobi, U.S. \& Ferreira, A.G. 1991. Efeitos alelopáticos de Mimosa bimucromata (DC) OK. sobre espécies cultivadas. Pesquisa Agropecuária Brasileira 26: 935-943.

Jefferson, L.V. \& Pennacchio, M. 2003. Allelopathic effects of foliage extracts from four Chenopodiaceae species on seed germination. Journal of Arid Environment 55: 275-285.

Jensen, W.A. 1962. Botanical histochemistry. San Francisco, W.H. Freeman and Company.

Johansen, D.A. 1940. Plant Microtechnique. New York, McGrawHill Book.

Kraus, J. E. and Arduin, M. 1997. Manual Básico de Métodos em Morfologia Vegetal. Seropédica, Brasil, Editora da Universidade Federal Rural do Rio de Janeiro.

Kraus, J.E. 1997. Respostas morfogenéticas de plantas a indutores galhadores. Pp. 59-76. In: M.C.P. Araújo; G.C. Coelho \& L. Medeiros (eds.). Interações Ecológicas e Biodiversidade. Ijuí, Brasil, Unijui.

Labouriau, L.G. \& Valadares, M.B. 1976. On the germination of seeds of Calotropis procera. Anais da Academia Brasileira de Ciências 48: 174-186.

Leicth, I.J. 1994. Induction and developmental of bean gall caused by Pontania proxima. Pp. 283-300. In: M.A.J. Wiliams (ed.). Plant galls: organisms, interactions, populations. New York, Oxford University Press.

Mani, M.S. 1964. Ecology of Plant Galls. The Hague, Dr. W. Junk Publishers.

Maraschin-Silva, F. \& Áquila, M.E.A. 2006. Potencial alelopático de espécies nativas na germinação e crescimento inicial de Lactuta sativa L. (Asteraceae). Acta Botanica Brasilica 20: 61-69.

Meyer, J. \& Maresquelle, H.J. 1983. Anatomie des Galles. Berlin, Gebrüder Borntraeger.

Miró, C.P.; Ferreira, A.G. \& Aquila, M.E.A. 1998. Alelopatia de frutos de erva-mate (llex paraguariensis) no desenvolvimento do milho. Pesquisa Agropecuária Brasileira 33: 1261-1270.

Nymam, T. 2000. Phylogeny and ecological evolution of gallinducing sawflies (Hymenoptera: Tenthredinidae). $\mathrm{PhD}$ Dissertations in Biology Unniversity of Joensuu.

Oliveira, D.C.; Christiano, J.C.S.; Soares, G.L.G. \& Isaias R.M.S. 2006. Reações de defesas químicas e estruturais de Lonchocarpus muehlbergianus Hassl. (Fabaceae) à ação do galhador Euphalerus ostreoides (Hemiptera, Psyllidae). Revista Brasileira Botânica 29: 657-667.

Periotto, F.; Perez, S.C.J.G.A. \& Lima, M.I.S. 2004. Efeito alelopático de Andira humilis Mart. Ex Benth na germinação e no crescimento de Lactuta sativa L. e Raphalus sativus L. Acta Botanica Brasilica 18: 425-430.

Pratley, J.E.; Na, M. \& Haig, T. 1999. Following a specific protocol estabilish allelophaty conclusively - an Australian case study. Pp. 63-70.In: A. Macias; J.C.G. Galindo; J.M.G. Molinillo \& H.G. Cutler (eds.). Recents Advances in Allelopathy. Cádiz, Servicio de Publicaciones, Universidad de Cádiz.

Rice, E.L. 1984. Allelopathy. London, Academic Press Inc.

Sall, J.; Lehman, A. \& Creighton L. 2002. JMP. Start Statistics. Cary, NC, USA, Sas Institute Inc.

Soares, G.L.G.; Scalon, V.R.; Pereira, T.O. \& Vieira, D.A. 2002. Potencial alelopático do extrato aquoso de folhas de algumas Leguminosas arbóreas brasileira. Floresta e Ambiente 9: 119-126.

Stephanou, M. \& Manetas, Y. 1997. The effects of sessons, exposure, enhanced UV-B radiation, and water stress on leaf epicuticular and internal UV-B absorbing capacity of Cistus creticus: a Mediterranean field study. Journal of Experimental Botany 48: 1977-1985.

Tang, C.; Cai, W.; Keith, K. \& Nishimoto, K. 1995. Plant stress and allelopathy. Pp. 142-157. In: K.M.M. Dakshini \& F.A. Einhellig (eds.). Allelopathy: organisms, processes, and applications. Iowa, Inderjit, University of Delhi.

Waller, G.R. 1999. Introduction. Pp. 63-70. In: F.A. Macias; J.C.G. Galindo; J.M.G. Molinillo \& H.G. Cutler (eds.). Recent Advances in Allelopathy. Cádiz, Servicio de Publicaciones, Universidad de Cádiz. 